\title{
Farmers' Capacity Strengthening in Facing the Challenges of Modernizing Agriculture in Karanggintung
}

\author{
Nurul Fatimah ${ }^{1}$, Resti Bona Yulita ${ }^{2}$ \\ $\left\{\right.$ \{fatimahnurul8@mail.unnes.ac.id $\left.{ }^{1}, \underline{\text { bonasosant@gmail.com }}^{2}\right\}$ \\ ${ }^{1}$ Department of Sociology and Anthropology, FIS UNNES, Indonesia \\ ${ }^{2}$ Nano Center Technology, Tangerang, Indonesia
}

\begin{abstract}
Modernization has penetrated all aspects of human life, including one of them in the agricultural community. Various efforts were made by farmers in order to harmonize with the existing modern developments from the way of farming, tools used, fertilizers used, even to cultivated plants. All these efforts are not enough to meet the expected development demands. One of the capitals that are able to drive community agriculture is through strengthening the capacity of the farmers themselves. This study aims to find out how to strengthen the capacity of farmers carried out by farmers to face the challenges of modernization in the village of Karanggintung. Data collection in this study was conducted using a qualitative approach. The informants in this study were farmers in the village of Karanggintung. Data retrieval is done by conducting observations, interviews and documentation. The data validity technique is done by triangulating data, namely source triangulation and methods. Data analysis is done using interactive data analysis. The results of the study show that the model of farmers' capacity strengthening to face the challenges of modernization is to strengthen existing social ties and deliberately formed by farmers. Factors that influence in social relationships are mutual trust between farmers, reciprocity among farmers and the demands of higher market needs. The weak strength of social ties that are built among farmers greatly influences the existence of farmers in Karanggintung village.
\end{abstract}

Keywords: Capacity strengthening, Challenges of modernization, Farmers, Social ties.

\section{Introduction}

Indonesia is an agrarian country where most of the population works as farmers. This can be seen from the data that the number of people working on agriculture occupies the largest number, which is calculated in 2015 at 40,122,815 (BPS, 2015). Farmers according to [1] are humans who are very static and economic activities. In Indonesia farmers are divided into two categories peasant and farmers. Peasant are farmers who cultivate but do not concentrate on business and most are still traditional. While the farmer is a farmer who has used modern tools and is very focused on business. Indonesia, most farmers are still classified as peasant.

Agricultural society in driving agricultural activities is dynamic. One of the influences on the dynamics of agricultural society is modernization. According to [2]modernization is a form of directed social change based on a plan which is usually called social planning. Modernization in agriculture is the modernization of the means of production. Modernization in agriculture in Indonesia is characterized by fundamental changes in agricultural patterns from traditional ways to more advanced ways. These changes include several things, including 
land management, use of superior seeds, use of fertilizers, use of agricultural production facilities, and regulation of harvest time. The changes in the socio-cultural system and structure of the peasant community began to change along with the entry of modernization in the New Order era, which was believed to be modernized and would improve the welfare of the community.

Modernization of agriculture developed since the New Order era when at that time a green revolution emerged as a government policy to improve the quality of agriculture in Indonesia In the Green Revolution there are three main components, namely the use of technology or five farms, the application of policies on the prices of facilities and production as well as credit and infrastructure support. Rural farmers who still rely on traditional methods have gradually chosen to use modern production tools. Apart from the effectiveness of production, it is also due to the efficiency of time and labor needed during production [3]. Rural farmers who have used modern production tools are usually by landowners (Farmers not Peasant) whose main work is not a farmer.

Most of the problems faced by farmers due to the modernization of agriculture are efforts to survive and exist in the midst of the current of modernization. Usually within constraints, farm workers will be increasingly eliminated and they will eventually go wander into big cities. Good solidarity between farmers and farm laborers or farm laborers with farm laborers is increasingly tenuous due to competition [4]. Modernization of agriculture is usually felt more positively on farmers who own capital than small farmers or farm laborers. [5]conveyed the same thing that agricultural modernization that took place in rural Maharashtra India, had the potential to give birth to and benefit more wealthy farmers as capital owners, while small farmers were increasingly left behind.

One of the consequences of modernization in agriculture is the decline in the role and presence of the state in managing and managing agriculture in the country. The third party in this case is that the private sector plays a more vital role, especially in the provision of various infrastructure used to develop modern agriculture. Another phenomenon seen in India, in agricultural management in India, is that the state and the private sector work together to develop agriculture in India, from upstream to downstream (from planting to processing of crops) [6]. Thus the industrialization of agriculture will be more easily achieved and able to improve the welfare of society equally for both farmers and the private sector.

Most of the people in Karanggintung Village are farmers. Farmers in Karanggintung Village are divided into landowners (Farmer) and cultivators or farm laborers (Peasant). Farmers who own land usually when the planting season arrives will require many farm workers to help work on their land starting from plowing fields, planting rice and doing maintenance while waiting for the rice to bear fruit. But at this time what happened was that landowners used tractors to plow fields, the use of rice harvesting machines shifted farm laborers to reap. Then the use of rice threshing tools (separating rice from the trunk) which usually requires $12-15$ farm workers can now only be done with 2-3 people as operators of the thresher. [7] openness of access to modern agricultural technology in India has an effect on the welfare of farmers. There are many costs and production costs to pay for farm laborers who do not have to be expelled again, but enough to be replaced with modern tools that are more effective and efficient. This makes the farmer less opportunities to be needed in the rice planting process until the rice harvest process. Although that, but farmers and farm workers in Karanggintung Village can survive and exsist. 


\section{Research Method}

This study using of qualitative approach. The location in this study is Karanggintung Village, Gandrungmangu Sub-District, Cilacap Regency. On the grounds that the initial observation found interesting finding. Usually farm workers who began to lose employment opportunities due to the gradual modernization of agricultural tools chose to go to the city to find work as factory workers or trade. But in the village of Karanggintung, farm workers chose to survive by choosing to do side jobs and farmers with extensive land still chose to use traditional farming systems in the production process in the hands of agricultural modernization that promised more profits.

The research subjects were farmers in Karanggintung Village.The main informants in this study were farmers who owned land (Farmers) and farm laborers (Peasant). Supporting informants in this study were the heads of farmer groups and village heads. The number of main informants in this study were 7 people while supporting informants were 5 people. The study was conducted from February 14 to March 15, 2017. During the research process there were no significant obstacles, only technical issues determined an agreed schedule for meeting with each informant. Nevertheless finally the interview and observation process went smoothly. Data collection uses documentation, observation and interviews. Data analysis uses qualitative data analysis methods consisting of data collection, data reduction, data presentation and conclusion drawing. This study uses rational choice theory from Coleman and farmers' moral morality from Scott as a theoretical basis.

\section{Result and Discussion}

Karanggintung Village is included in the Gandrungmangu District of Cilacap Regency. Overall, the Karanggintung Village is divided into 51 RTs and 6 RWs which are scattered in each hamlet. Karanggintung village is divided into 5 hamlets, namely Karanggintung Hamlet, Pagergunung Hamlet, Sindangraja Hamlet, Penumbang Hamlet and Karangtawang Hamlet. The total area of Karanggintung Village, which is 1284 ha, is not fully utilized for residential areas, but is also used for agricultural purposes and other public interests. To find out more clearly the distribution of the land area of Karanggintung Village.

The population in Karanggintung Village based on productive age is 5,485 people, most of whom work as farmers, namely $59.3 \%$ of the total productive age. Followed by $30 \%$ working as farm laborers. (Source: monograph of Karangginung Village, 2016). Based on the results of the 2013 agricultural census the total paddy field in Cilacap Regency reached 189,077 Ha (BPS, 2013). Modernization of agriculture began to enter the Karanggintung Village starting in the 2000s. In a period of about 17 years, little by little, the community, especially farmers, began to adopt a modern agricultural system.

\subsection{Modernization of agriculture and the impact that occurred in Karanggintung Village}

The use of modern production equipment. There are three modern production equipment are using Gebyok (a mechanical device used based on wood used to separate rice from the stem), using Rontogan (a machine tool used in wood-based materials used to separate rice from its stem), and use of tractor machines to plow fields. In addition to helping work efficiency, the use of tractors also creates its own problems both air pollution and noise. [8]in their study showed the impact of the use of tractor engines in agricultural activities on health 
and the duration of life of the tractor driver. The noise generated from the sound of the tractor every day turned out to be very influential not only on hearing, but on the health of the body of the tractor user.

\section{The use of modern production tools}

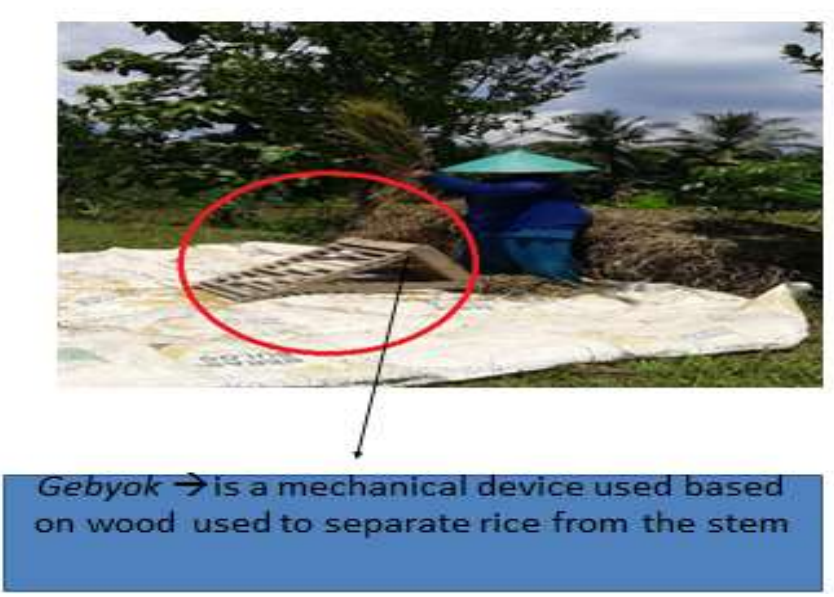

Figure 1. Gebyok is a mechanical device used based on wood used to separate rice from the stem.

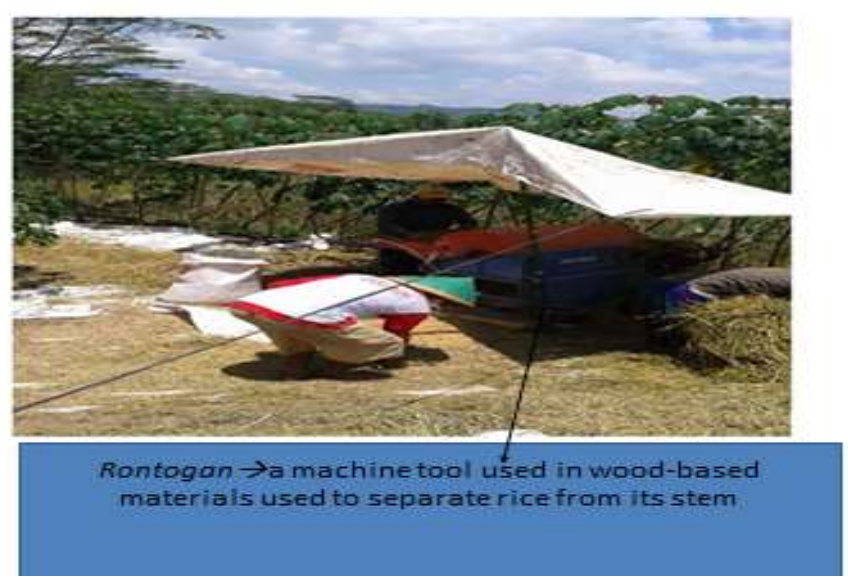

Figure 2. Rontogan is a machine tool used in wood-based materials used to separate rice from its stem 


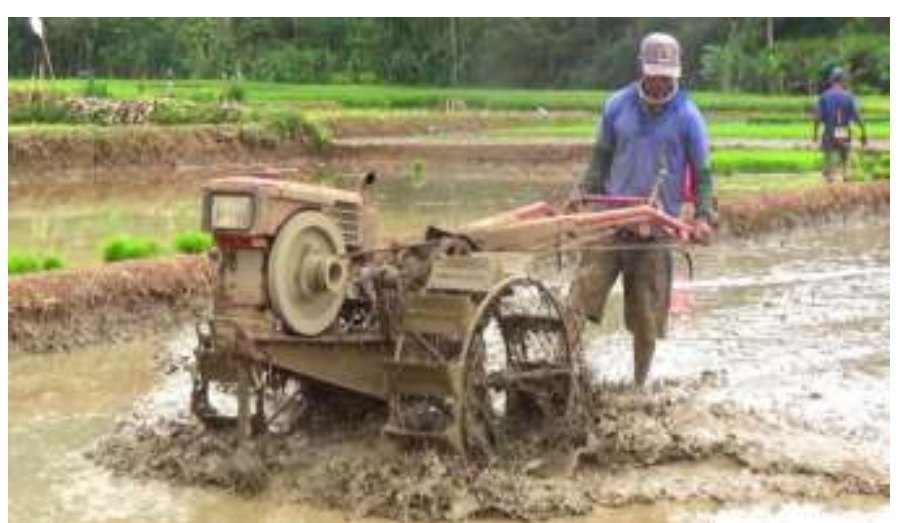

Figure 3. Tractor machines to plow fields

Use of chemical production materials. The agricultural production process is now more effective and efficient because, it does not have to sow the seeds themselves, don't have to making fertilizers and pesticides from manure and in processing the soil can use a tractor. So that the work is completed faster and does not require a lot of human labor. Because rational according to one individual is different from other individuals [9]

The wage systems. The system of payment of wages when the rice production process is usually there is a system that is sauran (payment) where the owner farmer helps each other when the other owner farms harvests or tandur. Farm workers will be given wages in the form of grain or rice by the landowner. This is not often found in agriculture in Karanggintung Village because most choose to pay wages in the form of money.

Extension and dissemination of agriculture. There is socialization and training of farmer groups from companies that issue new products in agriculture, for example pesticides. With the socialization of the company, the farmers finally learned that the use of pesticides was more practical to repel pests. Socialization and training of companies that want to introduce agricultural products. Agricultural extension is provided by agricultural staff from the process of preparing, planting, maintaining to harvesting. The theories conveyed by agricultural officers are not always in line and can be accepted by farmers. This happens because farmers already have their own habits and methods in carrying out their agricultural activities. [10]in her study of farmers in 4 Asian countries namely Thailand, Myanmar, Vietnam and Sri Lanka (Moonson Asia) showed that the irrigation problem in land management had actually been managed by the agricultural service through agricultural irrigation services with various methods. Even so, farmers prefer to develop conventional methods that they have themselves because they are considered more effective in supporting their agricultural activities.

Orientation of seeking profit. A Farmers in the Karanggintung village before the introduction of agricultural modernization were still largely saving their crops for their daily needs and they sold their grain supplies when they needed money. But since the introduction of modernization in agriculture, many farmers have sold a large portion of their crops after being harvested, especially in food stores and rice traders in the market. [11]the farmer's market takes a very important role in the communication process and put in place agricultural results and maintain price stability. Interpersonal relations carried out among fellow farmers, agricultural entrepreneurs, owners of agricultural capital and farm laborers can be accommodated through activities that occur in the farmers' market. 
Occurrence of side jobs. The emergence of side jobs due to reduced employment opportunities of farm workers. Some farm workers in Karanggintung Village now choose to look for side jobs while waiting for someone to call them to work to help with rice production because more and more farmers who have chosen to use rontogan make their employment opportunities less. Choose to look for odd jobs, because their employment opportunities are gradually seized by modern tools and systems so they try to survive by doing odd jobs.

\subsection{Capacity building carried out by farmers in facing the challenges of modernizing agriculture}

Strengthening existing social ties. Previous social ties between farmers and farmers and the community. Form of activitieas are in rice production process (in the case of tractor rentals with fellow farmers and submit management of rice planting to someone who is trusted). In Mbagen Tradition (distributes harvests in the form of rice or grain to relatives or close neighbors as a form of gratitude for the harvest obtained). Usually people will get $1-2 \mathrm{~kg}$ of rice. This is believed to be a form of gratitude and sharing fortune to others who are close to them. Farmers who do not carry out this tradition will receive social sanctions. [12]the restructuring of the international Agrarian has regulated and institutionalized various rules in agriculture, one of which in terms of strengthening the capacity of peasent is to develop social solidarity between farmers through various possible activities.

Intentionally forming new farmers' social ties. New farmer social ties (between labour farmers (Peasant) and landowners (Farmers)). Form of activities are by farmers' groups are carried out routinely where in farmer groups, farmers can exchange information about agriculture with other farmer. Arisan of rice is arisan which is held once in one harvest where those participating in rice arisan must deposit rice or grain produced according to their ability to participate in arisan. Usually each representative of one name will be charged 1/2 quintal). Factors that influence their weak strength in establishing farmers' social ties are there is mutual trust between fellow farmers, reciprocity among farmers, there is a demand for higher market needs, the social ties built among farmers greatly influence the existence of farmers in the Karanggintung village. Pengembangan ikatan sosial yang baru tersebut merupakan bagian dari pengembangan sumber daya manusia dalam hal ini adalah di bidang pertanian. Tantangan dalam pertanian di Abad 21 ini semakin berat, dimana kebutuhan hasil pertanian semakin meningkat, sementara kepemilikan lahan untuk pertanian justru semakin menyempit [13].

\subsection{Constraints in Maintaining Farmers' Social Ties in the Middle of Agricultural Modernization}

The emergence of social jealousy. If seen from a tractor rental system, rontogan renting and queuing to get fertilizer when rare based on kinship and social closeness creates social jealousy in the community.

There is competition in getting production materials. A From the competition to get rice production materials which in certain times become scarce, especially those which have been subsidized, are difficult to obtain, making farmers' social relations tenuous because conflicts arise among farmers. If the conflict that occurs is greater, the social ties of farmers will become tenuous and will even cause problems in the community. However, in Karanggintung Village the problem of fertilizer scarcity is rare and when a conflict occurs only limited to the sensitivity of farmers who feel there is discrimination done by the shop owner who prioritizes kinship rather than queuing or ordering in advance. Vailability of 
fertilizers and seeds for rice production is usually scarcity especially when the planting season comes.

The more dominant farmers use modern agricultural production tools. The increasing number of farmers who use modern farming tools and methods, makes the opportunity to interact between land owners and farm workers increasingly tenuous. modern tools used no longer require a lot of labor to move it. therefore it affects the change in the orientation of farmers' social ties from farmers to fellow farmers to become farmers to agricultural companies and capital owners. Although using modern agriculture does not mean that farmers who own land do not face challenges in managing their agricultural land. Capital issues / obtaining credit, marketing of agricultural products to keep getting good prices and how to maintain the quality of the crops. Therefore, the presence and active participation of agricultural producer organizations is one thing that must be done [14].

Fading awareness to maintain social relation. One of the obstacles to maintaining farmers' social ties is the level of awareness to maintain relationships with group members. Some members of farmer groups often do not attend regular meetings every month. Even some of them have never attended regular meetings at all, but will attend when getting assistance from the government or company.

Lack of openness of farmers in depositing rice in arisan of rice activities. In rice arisan there are some farmers who sometimes deposit rice that has been stored for a long time because they have not harvested and do not want to borrow from other farmers. The mechanism for managing funds in each farming community is usually adjusted to the capabilities possessed by farmers. One model of farmer fund management that has been developed is on farmers in Japan, therefore it is a learning for farmers in other countries, one of which is Sri Lanka [15].

\section{Conclusion}

The modernization of agriculture which penetrated Karanggintung village was found in the aspects of the use of production equipment, the use of chemical production materials and the system of wages. The consequences of agricultural modernization include the existence of counseling and agricultural socialization from agricultural production companies, a new orientation emerged in seeking profits by selling crops, giving rise to the rational choice of farmers to continue farming in traditional ways and some who had turned to modern agriculture and the emergence of rationality of farm laborers to find side jobs because their roles began to shift.

Strengthening capacity carried out by farmers in the face of agricultural modernization is pursued through strengthening existing social ties and deliberately forming new social ties. Constraints faced in maintaining farmers' social ties include the emergence of social jealousy among farmers, competition in obtaining production materials, increasingly dominating modern agriculture, fading awareness in maintaining social relations and lack of openness among farmers, especially in arisan of rice activities.

\section{Acknowledgements}

Thank you for all the informants who participated in this research, both main and supporting informants. Thank you for all who have provided support, advice and motivation in completing the research. All parties who have helped in the research until the writing of this paper, which cannot be mentioned one by one. 


\section{References}

[1] J. Scott, Moral Ekonomi Petani Pergolakan dan subsistensi di Asia Tenggara. Jakarta: Pustaka LP3ES, 1983.

[2] S. Soekanto, Sosiologi Suatu Pengantar. Jakarta: Raja Grafindo Persada, 2012.

[3] D. Sary, "Perubahan Sosial Budaya Petani Lokal Dayak Keninjal di Kecamatan Belimbing Kabupaten Melawi," Sociologique, vol. 4, no. 1, pp. 1-9, 2016.

[4] F. Rohman, "Perubahan Pola Perilaku Sosial dan Ekonomi Buruh Tani Akibat Industrialisasi," Paradigma, vol. 02, no. 01, pp. 1-6, 2014.

[5] B. Mohanty, "Agricultural modernization in rural Maharashtra: Myth and reality," Soc. Change, vol. 31, no. 4, pp. 93-108.

[6] F. and Zhou, "The Private Sector and India's Agricultural Transformation," Glob. J. Emerg. Mark. Econ., vol. 9, no. 1-3, pp. 28-37, 2018.

[7] S. and Singh, "Access to Modern Agricultural Technologies and Farmer Household Welfare: Evidence from India," Millenn. Asia, vol. 6, no. 1, pp. 19-43, 2015.

[8] K. and Mehta, "Effect of age and duration of driving on hearing status of Indian agricultural tractor drivers," J. Low Freq. Noise, Vib. Act. Control, vol. 37, no. 4, pp. 1037-1044, 2018.

[9] J. Coleman, Dasar-dasar Teori Sosial. Bandung: Nusa Media, 2011.

[10] J. Perera, "Farmer's Behaviour in Rice Irrigation in Monsoon Asia: Facts and Fallacies," South Asia Econ. J., vol. 5, no. 1, pp. 146-161, 2004.

[11] B. Garner, "Communication at Farmers' Markets: Commodifying Relationships, Community and Morality," J. Creat. Commun., vol. 10, no. 2, pp. 186-198, 2015.

[12] R. Patel, "International Agrarian Restructuring and the Practical Ethics of Peasant Movement Solidarity," J. Asian Afr. Stud., vol. 4, no. 1-2, pp. 71-93, 2006.

[13] R. and Alex, "Human Resource Development for Modernizing the Agricultural Workforce," Hum. Resour. Dev. Rev., vol. 7, no. 4 December, pp. 374-386, 2008.

[14] S. Pravesh, "Leveraging Farmer Producer Organizations to Boost Production, Mitigate Risk and Strengthen Food Security: Lessons and Challenges," J. L. Rural Stud., vol. 1, no. 1, pp. 41-48, 2013.

[15] E. and Kobayashi, "Farmer Companies in Sri Lanka: Lessons from Agricultural Cooperatives in Japan," Millenn. Asia, vol. 4, no. 2, pp. 117-133, 2013. 